\title{
EFFECT OF PHYTASE SUPPLEMENTATION ON THE PERFORMANCE OF BABCOCK-380 LAYER HENS
}

\author{
MD. RUHUL AMIN AND ELLIYANA NADIA BT HAMIDI
}

Faculty of Agro Based Industry, Universiti Malaysia Kelantan, Locked Bag No 100, 17600 Jeli, Kelantan, Malaysia

Corresponding author: ruhulamin@umk.edu.my

\begin{abstract}
In order to examine the effect of phytase supplementation in the diet of laying hen this experiment was conducted with 30 commercial hybrid Babcock-380 layers of 73 weeks of age. The hens were grouped into 3 treatment groups and given microbial phytase (Rena Phytase 400) at levels $2.5,1.5$ and 0 (control) $\mathrm{g} / \mathrm{kg}$ feed in addition to their basal diet $(110 \mathrm{~g}$ commercial pellet/day). Records on egg production/group/day, egg mass weight/day, body weight of hens at the end of experimental period were taken and analysed. Results revealed that hen house egg production (HHEP) and egg weight $(\mathrm{EW})$ varied $(\mathrm{p}<0.05)$ among the treatment groups but level of phytase did not affect $(\mathrm{p}<0.05)$ body weight of hens. Both HHEP and EW were in order of 2.5>1.5>0 g/kg feed phytase group and all the means were significantly $(\mathrm{p}<0.05)$ different from each other within treatment groups. Microbial phytase supplementation in layer ration proved to be beneficial in terms of egg production and egg size even after 72 weeks of age of hens. Layer farms in Malaysia can use this technology to earn more profit.
\end{abstract}

KEYWORDS: Microbial phytase; laying hen; hen house egg production; egg weight; body weight of hens

\section{Introduction}

Phytate (phytic acid-inositol hexakis phosphate, a phosphorous compound) occurs abundantly in poultry feed since poultry ration composed of bulk seed materials. Ravindran et al (1995) recorded phytate phosphorous (P) as \% of total $\mathrm{P}$ were 72,60 and $77 \%$ for corn, soybean and rice bran, respectively. The phytate-bound phosphorous is largely unavailable to monogastric animals as they do not have natural phytase enzyme which is required to release $\mathrm{P}$ from dietary phytate. This limitation of poultry generates two vital issues viz i) Birds require exogenous bioavailable $\mathrm{P}$ in their diet which is costly ii) Excess $\mathrm{P}$ in the form of phytate occuring in the feed remains unutilized in the gut and is excreted through feces, thus posing significant pollution in the soil, air and surface water (Jalal and Schedeler, 2001). Furthermore, the presence of phytate in poultry feed ingredients restricts the effective utilization of organic $\mathrm{P}$ and other nutrients such as calcium, energy and amino acids in the alimentary tract (Ravindran et al, 1995). Studies have indicated that optimum intake and digestion of $\mathrm{P}$ with phytase reduces the release of $\mathrm{P}$ in manure by around 30\% (Soliman and Sanaa, 2010). Use of exogenous phytase in the poultry diet not only releases P from phytate but also forms complexes of phytase together with other essential nutrients leading to higher nutritional value of the diet (Boling et al, 2000; Keshavarz, 2003; Ceylan et al, 2003 and Panda et al, 2005). Supplementation of poultry feeds with microbial phytase have shown to increase $\mathrm{P}$ availability giving rise to increased feed conversion efficiency, egg production, egg weight and egg shell quality (Jalal and Schedeler, 2001). Inclusion of microbial phytase particularly from Aspergillus niger has been proven to be more fruitful than phytase from 
other sources (Selle and Ravindran, 2006). Modern hybrid layers start laying at 18-20 weeks of age and continue profitable laying upto the age of 72 weeks. Beyond 72 weeks, their egg production steadily drops down. That is the reason why they are disposed off from the farm after 72 weeks of age. Since exogenous microbial phytase when supplemented with feed gave considerable benefits in layers, it can be hypothesized that supplementation of phytase in the hen's diet may prolong the profitable productive life of hens beyond 72 weeks. The present experiment, therefore, was undertaken with the aims of analysing egg production, egg size, body weight and mortality of hens beyond 72 weeks, fed diet supplemented with phytase from A. niger.

\section{Materials and Methods}

The experiment was carried out at a layer chicken farm, in Taman Pertanian Kekal Kampung Tunku Abdul Rahman, Kuala Balah, Jeli, Kelantan, Malaysia. A total of 30, 73-weeks old commercial hybrid Babcock-380 hens were used in the study. The hens were randomly distributed into 3 groups each with 10 hens. Hens irrespective of groups were fed with $110 \mathrm{~g}$ commercial layer pelleted feed (Table 1). Additionally, hens of Group 1 and Group 2 were allocated phytase supplementation at the rate of 2.5 and $1.5 \mathrm{~g} / \mathrm{kg}$ feed, respectively according to the range given by Soliman and Sanaa (2001). Hens of Group 3 were control group without any supplementation of phytase. The microbial phytase used in this experiment is Rena Phytase 400 (Natuphos 1000-G) produced from $A$. niger in powdered form. This fungal phytase was manufactured and supplied by Gist-Brocades, the Netherlands and BSF, Germany which was reformulated and marketed by Renata Animal Health Ltd and purchased from Bangladesh. The experiment lasted for 46 days. Data on egg production, egg weight, body weight and mortality of hens were recorded.

Egg productions were recoded on group-day basis and calculated as hen house egg production per hen per day (HHEP) over a period of 46 days based on the following formula:

$$
\text { HHEP }=\frac{\text { Noof agge laid by a group of hems }}{10} \quad \text { (Singh and Kumar, 1994) }
$$

Average egg weight was calculated by total egg mass/no. of eggs in a given day and expressed in gram (g). The body weight of the hens were measured individually at the end of the experiment. Initial body weight of the hens were almost the same ( $p>0.05)$ in all the experimental hens. So any difference in final weight can be attributed to phytase supplementation.Data on HHEP, egg weight and hen's body weight were subjected to analysis of variance (ANOVA) to examine whether any difference exists between groups. Mean separation were performed by Duncan's New Multiple Range Test (DMRT) using SPSS version 11.0 when ANOVA was significant (Kaps and Lamberson, 2009).

\section{Results and Discussion}

Effects of different doses of phytase supplementation on the performance of laying hen are described under the following sub-headings;

Hen house egg production per hen per day (HHEP): ANOVA showed (Table2) that there was significant $(\mathrm{p}<0.05)$ difference among the treatment groups of hens in HHEP as a result of different doses of phytase. Hens in group 1, group 2 and group 3 fed phytase at the rate of $2.5,1.5$ and $0 \mathrm{~g} / \mathrm{kg}$ feed laid an average of $0.85,0.79$ and $0.69 \mathrm{egg} / \mathrm{hen} / \mathrm{day}$, respectively and each mean was significantly $(\mathrm{p}<0.05)$ discrepant from any other (Table 2$)$. The corresponding 
increased of HHEP in \% were 16 and 10 respectively in group 1 and group 2 , compared to control group. The HHEP increased linearly and significantly $(\mathrm{p}<0.05)$ with the increased of phytase. The increased in HHEP indicates that at the age of 72 weeks onwards, the hens still continued laying optimally which was not observed in the control group of hens fed $0 \mathrm{~g}$ phytase/kg feed. Hybrid laying hens are usually culled at 72 weeks because of older age and consequently lowered HHEP. This study shows that the laying period can be extended in older hens leading to a reduction in the replacement cost. The results are in good agreement with those of Mohammed et al (2010) who showed that phytase supplementation in diets containing rice bran at levels of 1.0, 1.5, 2.0, $2.5 \mathrm{~kg} /$ ton feed increased $(\mathrm{p}<0.01)$ hen-day egg production by $3.5 \%, 5.59 \% 7.47 \%$ and $5.42 \%$, respectively compared to the control group in commercial Hy-Line White-36 hens. Since there was ' 0 ' hen mortality during the experimental period in the current experiment, hen house and hen day egg production became similar indicator. Plumstead (2007) reported a similar effect of adding phytase in the laying hen's diet on hen day egg production. In his experiment, the addition of phytase at levels of $1.0,1.5,2.0$ and $2.5 \mathrm{~kg} / \mathrm{ton}$ feed resulted in an increased $(\mathrm{p}<0.01)$ average egg number over the entire laying period by $4.49,7.91,10.70$ and $7.75 \%$, respectively in comparison with that of control group. However, current results differ from their study in that there is potential of lengthening laying period of hybrid layers beyond 72 weeks of age apart from increasing feed conversion efficiency and number of eggs only.

Egg Weight (EW): Average EW in hens of Group 1 (2.5g phytase/kg feed ), Group 2 (1.5g phytase $/ \mathrm{kg}$ feed) and Group $3(0 \mathrm{~g}$ phytase $/ \mathrm{kg}$ feed) were 63.10, 61.56 and $59.95 \mathrm{~g}$ respectively. Difference between groups as revealed from ANOVA was significant $(\mathrm{p}<0.05)$ and the EW responded linearly with the change in level of phytase. All the group means were different from each other (Table 3). Peter (1992) noticed that layers fed diet with phytase had significantly higher EW than hens fed same diet except phytase. Ciftci et al, (2005) observed EW to be affected significantly and decreased linearly with phytase levels of 600, 300 and 0 IU/kg feed in experimental hens. Several authors came up with the opinion that supplementation of phytase enzyme in the poultry diet leads to improve in protein digestion and utilization (Korgenay, 1996; Sebastian et al, 1997) which might be the reason of deposition of augmented amount of egg content leading to bigger sized eggs. Mohammed et al (2010) however, reported that phytase supplementation caused a significant increase in hen-day egg production but EW at the same time decreased significantly. Significantly $(\mathrm{p}<0.05)$ higher EW was obtained in hens of group 1 and group 2 compred to the control group likely because of an improvement in the digestion and utilization of protein by the hens resulting from phytase supplementation in the diet (Korgenay, 1996; Sebastian et al, 1997).

Body weight $(\boldsymbol{B W})$ of hens: Table 4 shows that $\mathrm{BWs}$ of hens irrespective of groups were almost the same $(2.03 \mathrm{~kg}, \mathrm{p}>0.05)$. Since initial BWs (73 weeks) of hens were of insignificant difference, it indicates that level of phytase could not influence BW gain measured at 80 weeks of age. Sarker et al (2011) demonstrated that broiler type Japanese quail better utilized rice polish based diet with added exogenous microbial phytase which was reflected in growth and meat yields. Additional benefit obtained from phytase in the layers of the present experiment might be totally diverted to egg production that is supposed to happen. Because the genetics of the layers which have a tendency to manufacture eggs rather than building up of body tissues particularly at the older age. Documentation to compare the results of the present experiment as regards to body weight gain of hens as affected by phytase supplementation is lac 


\section{Conclusion}

Supplementation of microbial phytase in the layer diet proved to be significantly beneficial in terms of hen house egg production and egg weight but not in body weight of hens, 72 weeks of age onwards. For the first time in this study, significant increase of egg production, egg size and feed efficiency following exogenous phytase supplementation in the diet of layers beyond 72 weeks of age had been observed. However, research with different levels of phytase in connection with specific grain feed needs to be carried out in different phases of production because different cereal grains may have different proportion and kinds of phosphorus compounds in them. Therefore, it can be concluded that optimum laying phase can be extended beyond 72 weeks with the addition of microbial phytase in the layer diet. Egg production cycle of layers can be lengthened in a same flock by supplementing microbial phytase in hen's diet.

\section{References}

Boling, S. D, Douglas, M. W, Johnson, M. L, Wang, X, Parsons, C. M. and Koelkebeck, K.W 2000. The effect of various dietary levels of phytase and available phosphorous on performance of laying hens. Poult. Sci. 79: 535-538.

Ceylan, N, Sceideler, S. E and Stilborn, H.L 2003. High available phosphorous corn and phytase in layer diets. Poult. Sci. 82:789-795.

Ciftci, M., Dalkilic, B. and Ali Azman, M 2005. Effects of microbial phytase supplementation on feed consumption and egg production of laying hens. Int'1 J.Poult. Sci. 4:758-760.

Jalal, M.A and Schedeler, S. E 2001. Effect of supplementation of two different sources of phytase on egg production parameters in laying hens and nutrient digestibility. Poult. Sci. 80:1463-1471.

Mohammed, K. A, Toson, M. A, Hassanien, H. H. M , Soliman, M. A. H and Sanaa, H.M. El-Nagar 2010. Effects of phytase supplementation on performance and egg quality of laying hens fed diets containing rice bran. Egypt. Poult. Sci. 30 (III):649-659.

Kaps, M and Lamberson, W.R. 2009. Biostatistic for animal science - an introductory text (2nd edi). CABI.

Keshavarz, K. 2003. The effect of different levels of nonphytate phosphorous with and without phytase on performance of strains of laying hens. Poult. Sci. 82:71-91.

Kornegay, E.T 1996. Nutritional, environmental and economic considerations for using phytase in pigs and poultry diets. In: Kornegay, E.T (eds) Nutrient management of food animals to enhance and protect the environment, Chapter 18. pp 277-302 (Boca Raton, CRC press).

Panda, A. K, Rao, S. V. R, Raju, M. V. L. N and Bhanja, S. K 2005. Effect of microbial phytase on production performance of White leghorn layers fed on a diet low in nonphytate phosphorous. British Poult. Sci. 46: 464-469.

Peter, W. 1992. Investigations on the use of phytase in feeding laying hens. Proceedings XIX World Poultry Congress, Amsterdam, Netherland. Pp 672.

Plumstead, P.W 2007. Strategies to reduce fecal phosphorous excretion in the broiler industry without affecting performance. In: Mohammed, K. A, Toson, M. A., Hassanien, H. H. M., Soliman, M. A. H and Sanaa, H.M. El-Nagar 2010. Effects of phytase supplementation on performance and egg quality of laying hens fed diets containing rice bran. Egypt. Poult. Sci. 30 (III):649-659.

Ravindran, V; Bryden, W. L and Kornegay, E. T 1995. Phytase: Occurence, bioabailability and implication in poultry nutrition. Poultry avian biol. Rev 6: 125-143. 
Sarker, D. K; Mahiuddin, M; Ali, M. S; Azad, M. M. H and Howlider, M. A. R 2011. Exogenous phytase for better utilization of parboiled rice polish based diet on the growth and meat yield of Japanese quail. Bang. J. Anim. Sci. 40 (1-2): 8-12.

Sebastian, S; Touchburm, P; Chavez, E. R and Lague P.C 1997. Implication of phytic acid supplemental microbial phytase in poultry nutrition - a review. World Poult Sci., 54:27-47.

Selle, P. H and Ravindran, V 2006. Microbial phytase in poultry nutrition. Animal Feed Sci. Tech. 135 (1-2): 1-41.

Singh, R.P and Kumar, J 1994. Measurements of economic traits. In: Biometrical methods in poultry breeding (first edi). Kalayani Publishers, New Delhi. Pp 8-12.

Soliman, M.A.H and Sanaa, H.M 2001. Effect of phytase supplemention on performance and egg quality of laying hens fed diets containing rice bran. Egypt. Poult. Sci. 30 (III): 649-659.

Table 1: Composition of the layer ration (commercial pellet)

\begin{tabular}{|l|l|}
\hline Ingredients & Amount in parts \\
\hline Corn & 640 \\
Soybean meal $(46 \%$ & 225 \\
CP) & \\
Limestone & 85 \\
\hline Components & $\%$ \\
\hline Crude protein & 16.50 \\
Crude fat & 3.25 \\
Calcium & 3.60 \\
Total phosphorous & 0.50 \\
Lysine & 0.82 \\
Methionine+cystine & 0.67 \\
\hline Energy & \\
\hline Metabolizable energy & $2725 \mathrm{kcal} / \mathrm{kg}$ feed \\
\hline
\end{tabular}

Table 2: Hen house egg production (HHEP)/hen/day

\begin{tabular}{|c|l|c|c|c|c|}
\hline Group & $\begin{array}{l}\text { Level of } \\
\text { phytase }(\mathrm{g} / \mathrm{kg} \\
\text { feed) }\end{array}$ & No. of hens & $\begin{array}{l}\text { Study period } \\
(\text { days })\end{array}$ & $\begin{array}{l}\text { HHEP/hen/day } \\
(x \pm S E)\end{array}$ & $\begin{array}{l}\text { Difference } \\
\text { from control }\end{array}$ \\
\hline 1 & 2.5 & 10 & 46 & $0.85^{\mathrm{a}} \pm 0.017$ & 0.16 \\
2 & 1.5 & 10 & 46 & $0.79^{\mathrm{b}} \pm 0.018$ & 0.10 \\
3 & 0 & 10 & 46 & $0.69^{\mathrm{c}} \pm 0.018$ & 0 \\
F-value & & & & $21.503^{*}$ & \\
\hline
\end{tabular}

Means with different superscripts differ significantly $(\mathrm{p}<0.05)$

$* \mathrm{p}<0.05$

\begin{tabular}{|ll|l|l|l|ll|l|}
\hline Table 3: & Egg & Level of & No. of hen & Study period & Egg weight & Difference \\
\hline
\end{tabular}




\begin{tabular}{|l|l|l|l|l|c|}
\hline $\begin{array}{l}\text { weight } \\
\text { affected } \\
\text { phytase } \\
\text { supplementation } \\
\text { Group No }\end{array}$ & $\begin{array}{l}\text { phytase } \\
(\mathrm{g} / \mathrm{kg} \text { feed })\end{array}$ & & (days) & $(\mathrm{g})(x \pm 5 E)$ & from control \\
\hline 1 & 2.5 & 10 & 46 & $63.10^{\mathrm{a}} \pm 0.528$ & 3.15 \\
2 & 1.5 & 10 & 46 & $61.56^{\mathrm{b}} \pm 0.399$ & 1.61 \\
3 & 0 & 10 & 46 & $59.95^{\mathrm{c}} \pm 0.412$ & 0 \\
F-value & & & & $12.17^{*}$ & \\
\hline
\end{tabular}

Means with different superscripts differ significantly $(\mathrm{p}<0.05)$

$* \mathrm{p}<0.05$

Table 4: Body weight of hens as affected by phytase supplementation at the end of the experiment

\begin{tabular}{|c|l|c|c|l|l|}
\hline Group & $\begin{array}{l}\text { Level of } \\
\text { phytase }(\mathrm{g} / \mathrm{kg} \\
\text { feed) }\end{array}$ & No. of hen & $\begin{array}{l}\text { Study period } \\
\text { (days) }\end{array}$ & $\begin{array}{l}\text { Body weight } \\
\text { of hens }(\mathrm{kg}) \\
(x \pm S E)\end{array}$ & $\begin{array}{l}\text { Difference } \\
\text { from control }\end{array}$ \\
\hline 1 & 2.5 & 10 & 46 & $2.030 \pm 0.075$ & 0.0021 \\
2 & 1.5 & 10 & 46 & $2.028 \pm 0.074$ & 0 \\
3 & 0 & 10 & 46 & $2.028 \pm 0.074$ & 0 \\
F-value & & & & 0.028 NS & \\
\hline
\end{tabular}

NS, not significant $(\mathrm{p}>0.05)$ 